\title{
PROFITABILITAS STRATEGI MOMENTUM DI BURSA EFEK INDONESIA (PERIODE JANUARI 2003 - DESEMBER 2007)
}

\author{
B Yuliarto Nugroho \\ Departemen Ilmu Administrasi \\ Fakultas Ilmu Sosial dan Ilmu Politik \\ Universitas Indonesia \\ e-mail: nugroho_yuliarto@yahoo.com
}

\begin{abstract}
Momentum trading strategy present challenges to the concept of efficient market theory. Many studies investigate the profitability of momentum trading strategy in international and domestic equity market and evidence has shown that this strategy could lead to abnormal profit. The purpose of this paper are to examine and analyse the profitability of momentum strategy in the Indonesia equity market from January 2003 to December 2007. This paper also investigates factor such as size and trading volume to identify potential source of profits in momentum strategy. The result of this research show that short-term momentum strategy are profitable on all stock listed on IDX. The findings of the research also show that in the shortterm, trading volume have significant effects and could be potential source of profits in momentum strategy.
\end{abstract}

Keywords:profitability, momentum, size, trading volume .

\section{PENDAHULUAN}

Efficient market hypothesis menyatakan bahwa harga saham mencerminkan semua informasi yang tersedia sehingga memberikan implikasi dimana investor tidak dapat memprediksi return yang ingin diperoleh. Jika pasar efisien maka tidak ada kemungkinan bagi investor untuk memprediksi pergerakan harga berdasarkan harga masa lalu untuk mendapatkan abnormal return. Sehingga, dalam pasar efisien pergerakan harga tidak dapat diprediksi dan harga bergerak dalam bentuk acak (random walk). Namun, dengan adanya arbitrase dalam mekanisme perdagangan, investor dapat memprediksi pergerakan harga dengan menggunakan informasi harga di masa lalu untuk menghasilkan keuntungan (abnormal return). Dalam memprediksi pergerakan harga untuk menghasilkan keuntungan telah banyak menggunakan strategi perdagangan seperti momentum dan kontrarian strategi untuk menghasilkan abnormal return. Strategi momentum mengacu pada suatu pola dalam jangka waktu pendek dan menengah (khususnya 3 sampai dengan 12 bulan) di mana saham-saham yang berkinerja baik (winners) dan memberikan keuntungan pada investor di masa lalu terus menunjukkan kinerja yang baik, dan sebaliknya, saham-saham yang berkinerja buruk (losers) di masa lalu terus menunjukkan kinerja buruk pula.

Pokok permasalahan dari penelitian ini adalah: (1) Apakah ada profitabilitas strategi momentum pada perusahaan yang terdaftar di Bursa Efek Indonesia selama periode 2003 - 2007, (2) Apakah terdapat pengaruh size terhadap profitabilitas strategi momentum pada perusahaan yang terdaftar di Bursa Efek Indonesia selama periode 2003 - 2007, (3) Apakah terdapat pengaruh volume perdagangan terhadap profitabilitas strategi momentum pada perusahaan yang 
terdaftar di Bursa Efek Indonesia selama periode 2003 - 2007. Untuk itu tujuan dari penelitian ini untuk menjawab permasalahan dari penelitian ini dan dapat bermanfaat bagi dunia akademis serta relitasnya dalam dunia investasi nyata.

\section{TINJAUAN PUSTAKA}

Pengertian efek momentum secara umum di kalangan praktisi keuangan, khususnya pasar modal, mengacu ada suatu keadaan dalam jangka pendek atau menengah yang dapat dimanfaatkan keuntungan melalui aktivitas perdagangan. Dalam penelitian ini, pengertian efek momentum mengacu pada apa yang dimaksud oleh Jegadeesh dan Titman (1993) dan penelitian-penelitian mengenai momentum sesudahnya. Penelitian yang dilakukan Gleser dan Weber (2002) mereplikasi penelitian yang terdahulu, yaitu suatu pola dalam jangka waktu menengah (khususnya 3 sampai dengan 12 bulan) di mana sahamsaham yang berkinerja baik (winners) dan memberikan keuntungan pada investor di masa lalu terus menunjukkan kinerja yang baik, dan sebaliknya, saham-saham yang berkinerja buruk (losers) di masa lalu terus menunjukkan kinerja buruk pula. Dengan kata lain, pergerakan harga saham individual dalam jangka waktu menengah cenderung untuk mengikuti suatu pola tertentu, yang konsekuensinya investor dapat menggunakan pola tersebut untuk meramal harga saham dalam masa depan, serta untuk melakukan suatu strategi perdagangan yang bertujuan mendapatkan abnormal return.

Beberapa penelitian, seperti Jegadeesh dan Titman (1993), Rouwenhorst (1998 dan 1999), Chui, Titman dan Wei (2000), Lee dan Swaminathan (2000), Glaser dan Weber (2002), melaporkan bahwa eksploitasi strategi momentum (untuk selanjutnya disebut dengan momentum) memang menghasilkan keuntungan yang cukup signifikan. Momentum tidak tampak pada periode pendek, yaitu 1 bulan atau kurang dimana pada rentang waktu tersebut, harga-harga akan cenderung tampak lebih acak. Sebaliknya DeBont dan Thaler (1985) mengatakan bahwa pada jangka waktu lebih dari 1 tahun, biasanya terjadi proses pembalikan atas pola kembalian sahamsaham individual. Womack (1996) juga melaporkan bahwa para analis secara umum lebih suka merekomendasikan saham-saham yang bermomentum tinggi daripada sahamsaham yang bermomentum rendah.

Banyak penelitian yang telah mencoba untuk mengidentifikasi faktorfaktor yang dapat menjelaskan profitabilitas momentum, yakni melihat dari faktor size. Beberapa penelitian telah mengemukakan tentang pengaruh size terhadap berbagai macam faktor. Penelitian Gretler (1988) menyatakan bahwa informasi berdasarkan batasan-batasan keuangan (financial constraint) akan sangat mungkin berdampak pada perusahaan kecil dibandingkan perusahaan besar dikarenakan perusahaan besar cenderung lebih "dewasa" dan lebih banyak memiliki hubungan dengan penyedia jasa keuangan. Drakos dan Kalandris (2005) menggunakan size kedalam salah satu firm specific attribute sebagai proxy kekuatan informasi asimetris (severity of asymmetric information). Mereka mengatakan bahwa perusahaan kecil sangat mungkin untuk terkena idiosyncratic risk dan ada kemungkinan perusahaan akan kurang dikenal di pasar modal sehingga investor dapat membedakan mana perusahaan yang baik dan buruk.

Beberapa penelitian lainnya seperti Fama dan French (1992) menunjukkan adanya hubungan yang signifikan antara firm size, market to book dan return sekuritas untuk perusahaan non-keuangan. Mereka membuktikan bahwa rata-rata return pada pasar saham Amerika Serikat tidak memiliki hubungan dengan beta dan book to market dan firm size adalah variabel 
dominan yang dapat menjelaskan cross sectional return. Sama seperti Fama dan French, Barber dan Lyon (1997) menunjukkan hubungan yang sama antara firm size dan book-to-market ratio untuk perusahaan keuangan dan non-keuangan, sekurangkurangnya kedua variable tersebut berhubungan dengan security returns. Penelitian tersebut menyatakan bahwa size dan book to market ratio dapat menjelaskan secara ekonomi mengenai perbedaan perpotongan pada pengembalian sekuritas. Di penelitian lainnya Hong dan Stein (1999) dan Hamed dan Kusnadi (2002) menemukan bahwa perusahaan kecil (small firm size) memiliki return yang tinggi daripada perusahaan besar dan profitabilitas momentum menjadi lebih kecil saat kapitalisasi pasar meningkat.

Penelitian yang dilakukan Chan, Hamed dan Tong pada pasar modal internasional yang menguji profitabilitas strategi momentum bahwa terdapat momentum profit yang signifikan (2000). Mereka menemukan momentum yang sangat kuat yang diikuti kenaikan volume perdagangan. Lee dan Swaminathan menguji hubungan antara momentum, volume dan return dalam jangka panjang untuk menguji behavioral model (2000). Mereka menunjukkan bahwa volume perdagangan masa lalu memberikan keterkaitan yang penting antara momentum dan strategi nilai.

Dari beberapa penelitian, seperti Fama dan French (1992) juga penelitian Sagi dan Seasholes (2007) terdapat adanya bukti keterkaitan antara profitabilitas momentum dengan variabel-variabel seperti likuiditas, market to book ratio, earnings, size, firm-specific attributes dan juga dapat dilihat dari kelompok industri perusahaan itu sendiri. Dengan demikian, berdasarkan beberapa penelitian sebelumnya maka penulis menitikberatkan mengenai pengujian profitabilitas strategi momentum yang dipengaruhi oleh size (market capitaliztion) dan trading volume terhadap profitabilitas strategi momentum pada perusahaan yang terdaftar di Bursa Efek Indonesia periode 2003 sampai dengan 2007.

Dengan demikian hipotesis yang disusun untuk profitabilitas strategi momentum adalah:

H1 : saham winners akan terus menjadi saham winners dan saham losers akan terus menjadi saham losers.

Sedangkan untuk hipotesis profitabilitas strategi momentum yang dilihat dari variabel size yaitu sebagai berikut:

H2 : Profitabilitas momentum lebih tinggi pada perusahaan kecil

Sedangkan untuk hipotesis profitabilitas strategi momentum yang dilihat dari variabel trading volume yaitu sebagai berikut:
H3 : Profitabilitas momentum lebih tinggi pada perusahaan dengan volume perdagangan yang tinggi.

\section{METODE PENELITIAN}

Berdasarkan pendekatan penelitian, penelitian ini merupakan penelitian kuantitatif yaitu berangkat dari kerangka pemikiran dan teori untuk dikembangkan menjadi suatu analisis data, dimana pendekatan ini lebih berdasarkan pada data yang dapat dihitung untuk mendapatkan penaksiran kuantitatif yang kuat. Teknik pengumpulan data yang dilakukan oleh peneliti dalam penelitian ini menggunakan analisis data sekunder, yaitu dengan mencari data mengenai harga saham-saham yang terdaftar pada Bursa Efek Indonesia selama periode Januari 2003 sampai dengan Desember 2007. Sedangkan data-data yang dikumpulkan berupa closing price harian masing-masing saham, size (market capitalization) dan volume perdagangan (trading volume) berasal dari Bursa Efek Indonesia, ICMD dan Osiris. 
Penelitian ini menggunakan metodologi yang diterapkan pertama kali oleh Jegadeesh dan Titman (1993) di dalam penelitiannya untuk menguji profitabilitas momentum. Pada penelitian ini, pertama proses periode pembentukan dilakukan dimana seluruh saham yang tercatat pada Bursa Efek Jakarta diurutkan berdasarkan lagged return saham masa lalu untuk periode 1, 3, 6, 9 dan 12 bulan (diberi kode J, J3 untuk 3 bulan, J6 untuk 6 bulan dan seterusnya) atau disebut formation period. Selanjutnya, disusun periode pengujian dalam suatu periode tertentu (holding period) selama periode 1, 3, 6, 9 dan 12 bulan (diberi kode $\mathrm{K}$, yaitu K3 untuk holding period 3 bulan, K6 untuk holding period 6 bulan dan seterusnya). Jadi terdapat 2 periode penting pada strategi ini yaitu periode pembentukan (formation) dan periode pengujian (holding). Sehingga secara total akan terbentuk 25 strategi.

Kemudian pada setiap $\mathrm{t}$ bulan $(1,3$, 6, 9 dan 12 bulan), keseluruhan saham saham dirangking secara descending berdasarkan lagged return dan dibagi kedalam 5 quintile portofolio secara equallyweighted portfolio. Setelah itu ditentukan top quintile (q1) atau sebagai portofolio winner dengan return tertinggi (future winner) dan bottom quintile (q5) atau sebagai portofolio loser dengan return terendah (future loser). Oleh karena itu, pada bulan ke-t pembentukan portofolio winner-loser (future winner - future loser) memungkinkan investor untuk melakukan strategi perdagangan dengan menjual future loser portofolio dan membeli future winner portfolio. Setelah itu, dihitung mean return untuk masing-masing portofolio winner dan loser pada setiap periode $(\mathrm{J} / \mathrm{K})$.

Sebagai ilustrasi, misalkan strategi (J3/K6) yang artinya dilakukan penilaian untuk 3 bulan lalu dan disusun berdasarkan lagged return. Kemudian di-hold selama 6 bulan kedepan. Misalkan, periode penilitian
Januari 2002 sampai dengan Desember 2003, maka selama 3 bulan, Januari - Maret 2002 melakukan penilaian kemudian hasilnya yang berupa portofolio (misalnya terdiri dari saham A, B, C dan D) di-hold selama periode 6 bulan kedepan yaitu April sampai September 2002. Kemudian melakukan penilaian kembali untuk periode April - Juni 2002, selanjutnya portofolio bentukan (misalnya terdiri dari saham $\mathrm{D}, \mathrm{F}$, $\mathrm{G}$ dan $\mathrm{H}$ ) dipegang di-hold untuk 6 bulan kedepan yaitu Juli - Desember 2002. Begitu seterusnya hingga periode penelitian berakhir pada Desember 2003.

Pada penyusunan metode portofolio dalam penelitian ini, return portofolio dihitung berdasarkan buy and hold return untuk kedua portofolio winner dan loser tersebut.

$$
R_{t j}=\frac{I H S I_{t}-I H S I_{t-1}}{I H S I_{t-1}}
$$

Dimana,

$R_{i j}=$ buy and hold return sekuritas $\mathrm{i}$ pada periode formasi $\mathrm{j}$

$I H S I_{t}=$ harga penutupan pada hari $t$ sekuritas i pada periode formasi $\mathrm{j}$

$I H S I_{t-1}=$ harga penutupan pada hari $t-1$ sekuritas i pada periode formasi $\mathrm{j}$

Langkah selanjutnya dalam metode ini adalah menentukan profit yakni dimana mean return portofolio winner dikurangi dengan mean return portofolio loser

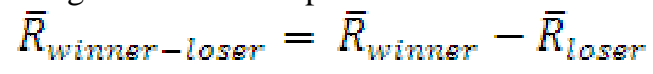

\section{Test Statistik: Uji t-test}

Penelitian ini juga melakukan penghitungan uji statistik dengan menggunakan uji t. Hal ini dilakukan untuk menentukan apakah portofolio winner dan portofolio loser secara statisitik berbeda 
dengan nol. Formula penggunaan statistik uji t yakni sebagai berikut:

$$
t=\frac{\mu_{\text {winner }}-\mu_{\text {loser }}}{\sqrt{\frac{\sigma_{\text {winner }}^{2}}{N_{\text {winner }}}+\frac{\sigma_{\text {loser }}^{2}}{N_{\text {loser }}}}}
$$

$\boldsymbol{\mu}_{\text {winner }}$ : mean monthly return dari portofolio winner $\mathrm{K}(3,6,9$, dan 12) bulan

$\boldsymbol{\mu}_{\mathrm{loser}}$ : mean monthly return dari portofolio loser K (3, 6, 9, dan 12) bulan

$\boldsymbol{\sigma}_{\text {winner }}$ : varian dari portofolio winner $\mathrm{K}$ $(3,6,9$, dan 12) bulan

$\boldsymbol{\sigma}^{2}$ loser : varian dari portofolio loser K (3, 6, 9 dan 12) bulan

$\mathbf{N}_{\text {winner }}$ : jumlah observasi dari portofolio winner $\mathrm{K}$ (3, 6, 9 dan 12) bulan

$\mathbf{N}_{\text {loser }}$ : jumlah observasi dari portofolio loser K (3, 6, 9, dan 12) bulan

\section{HASIL ANALISIS DAN PEMBAHASAN}

Berikut ini merupakan pemaparan hasil pengujian yang telah dilakukan untuk membuktikan profitabilitas strategi momentum di Bursa Efek Indonesia. Data yang digunakan dalam penelitian ini menggunakan data saham selama periode Januari 2003 sampai periode Desember 2007 dengan jumlah 385 saham.

Tabel 1 di bawah ini merupakan statistik deskriptif karakteristik dari semua saham yang dijadikan sampel dalam penelitian ini. Hasil dari panel A menunjukkan nilai dari mean, median, min dan max dari masing-masing variabel baik dari price, size dan volume. Untuk size dan volume nilai minimalnya bernilai 0 karena ada emiten yang tidak memiliki data size dan volume sehingga nilainya nol. Sedangkan dari Panel B menunjukkan excess return di pasar untuk masa 1, 3, 6, 9 dan 12 bulan untuk semua sampel saham. Nilai mean dari excess return bernilai positif untuk semua bulan sehingga menimbulkan kecenderungan dari nilai positif untuk semua bulan akan membentuk pola yang sama.

Tabel 1: Statistik Deskriptif

Panel A

\begin{tabular}{lrrrr}
\hline & \multicolumn{1}{c}{ Mean } & Median & Min & \multicolumn{2}{c}{ Max } \\
\hline semua saham & & & & \\
Price (Rp) & 2366,83 & 400 & 5 & 408400 \\
Size (Rp milyar) & 327,46 & 22,32 & 0 & 4058 \\
Trading Volume & 4699981 & 7000 & 0 & 208445050 \\
\hline Panel B & \multicolumn{3}{c}{ Mean } \\
\hline & 0,0223 & 0 & $-0,9366$ & 0,9841 \\
\hline excess return in market 1 bulan & 0,0512 & 0 & $-0,9577$ & 0,9892 \\
excess return in market 3 bulan & 0,0735 & 0 & $-0,9647$ & 0,9863 \\
excess return in market 6 bulan & 0,0855 & 0,0143 & $-0,9500$ & 0,9903 \\
excess return in market 9 bulan & 0,0858 & 0,0208 & $-0,9636$ & 0,9924 \\
excess return in market 12 bulan & \multicolumn{2}{c}{ Median }
\end{tabular}

Sumber: pengolahan data penulis 
Profitabilitas Strategi Momentum Dari hasil pengujian terhadap profitabilitas strategi momentum dimana penelitian menghitung periode holding winner return dan winner loser selama periode penilaian. Jika didapatkan hasil yang berbeda antara winner return dan loser return (zero cost portfolio) yang secara signifikan lebih besar dari nol (Winner Loser $>0$ ) maka dapat dikatakan bahwa terdapat profitabilitas momentum.

Tabel 2 dibawah ini menunjukkan profitabilitas strategi momentum untuk semua saham yang terdaftar di IDX (385 saham). Pembentukan portfolio berdasarkan return saham masa lalu pada $\mathrm{J}$ bulan (formation period) dan dinilai untuk K bulan (holding period). Semua saham diurutkan secara descending berdasarkan buy-hold return. Kemudian dibentuk 5 quintile portfolio. Pada $\mathrm{J}$ bulan, winner quintile adalah quintile dengan return saham tertinggi sedangkan loser quintile dengan return saham terendah. Kemudian di-hold untuk $\mathrm{K}$ bulan berikutnya. Setalah itu dihitung rata-rata return dari winner quintile dan loser quintile dan dihitung selisih antara quintile winner dan quintile loser (zero cost). Juga dilakukan uji $\mathrm{t}$ dengan signifikansi 5\%.

Tabel 2 di bawah menunjukkan profitabilitas momentum secara signifikan terlihat pada periode formasi (formation period) 3, 6, 9 dan 12 bulan dan pada periode penilaian (holding period) untuk 3 bulan. J3/K3 menghasilkan profit sebesar 6,9 \%, untuk periode J6/K3 menghasilkan profit sebesar $9,32 \%$, sedangkan untuk periode J9/K3 menghasilkan profit sebesar $10,46 \%$ dan untuk J12/K3 menghasilkan profit sebesar 11,28\%. Sehingga dapat dilihat momentum terjadi pada periode jangka pendek yakni dalam 3 bulan. Profitabilitas momentum terbaik terdapat pada J12/K3 yakni dengan profit sebesar $11,28 \%$.

Tabel 2: Portfolio Profitabilitas Strategi Momentum

\begin{tabular}{ccccccc}
\hline \multirow{2}{*}{ Formation } & & \multicolumn{5}{c}{ Holding Period $(\mathbf{K})$} \\
\cline { 3 - 7 } Period $(\mathbf{J})$ & Portofolio & K=1 & K=3 & K=6 & K=9 & K=12 \\
\hline J=1 & Winner & 0,02342 & 0,02290 & 0,02256 & 0,02386 & 0,01984 \\
& Loser & $-0,01446$ & $-0,00859$ & 0,00438 & $-0,00339$ & 0,00243 \\
& W $-\mathbf{L}$ & $\mathbf{0 , 0 3 7 8 8}$ & $\mathbf{0 , 0 3 1 4 9}$ & $\mathbf{0 , 0 2 6 9 4}$ & $\mathbf{0 , 0 2 7 2 5}$ & $\mathbf{0 , 0 2 2 2 7}$ \\
$\mathbf{J}=\mathbf{3}$ & Winner & 0,03867 & 0,03740 & 0,01796 & 0,00717 & 0,00308 \\
& Loser & $-0,02178$ & $-0,03161$ & $-0,02813$ & $-0,02996$ & $-0,03142$ \\
& W $-\mathbf{L}$ & $\mathbf{0 , 0 6 0 4 5}$ & $\mathbf{0 , 0 6 9 0 1}$ & $\mathbf{0 , 0 4 6 0 9}$ & $\mathbf{0 , 0 3 7 1 3}$ & $\mathbf{0 , 0 3 4 5 0}$ \\
$\mathbf{J}=\mathbf{6}$ & Winner & 0,04988 & 0,04175 & 0,01547 & $-0,00467$ & $-0,01640$ \\
& Loser & $-0,02777$ & $-0,05143$ & $-0,05909$ & $-0,05770$ & $-0,05806$ \\
& W $-\mathbf{L}$ & $\mathbf{0 , 0 7 7 6 5}$ & $\mathbf{0 , 0 9 3 1 8}$ & $\mathbf{0 , 0 7 4 5 6}$ & $\mathbf{0 , 0 5 3 0 3}$ & $\mathbf{0 , 0 4 1 6 6}$ \\
$\mathbf{J}=\mathbf{9}$ & Winner & 0,05687 & 0,04212 & 0,01371 & $-0,00686$ & $-0,02218$ \\
& Loser & $-0,03198$ & $-0,06249$ & $-0,07467$ & $-0,07502$ & $-0,07311$ \\
& W $-\mathbf{L}$ & $\mathbf{0 , 0 8 8 8 5}$ & $\mathbf{0 , 1 0 4 6 1}$ & $\mathbf{0 , 0 8 8 3 8}$ & $\mathbf{0 , 0 6 8 1 6}$ & $\mathbf{0 , 0 5 0 9 3}$ \\
$\mathbf{J}=\mathbf{1 2}$ & Winner & 0,06038 & 0,04367 & 0,01082 & $-0,01153$ & $-0,02617$ \\
& Loser & $-0,03589$ & $-0,06919$ & $-0,08068$ & $-0,08227$ & $-0,08140$ \\
& W $-\mathbf{L}$ & $\mathbf{0 , 0 9 6 2 7}$ & $\mathbf{0 , 1 1 2 8 6}$ & $\mathbf{0 , 0 9 1 5 0}$ & $\mathbf{0 , 0 7 0 7 4}$ & $\mathbf{0 , 0 5 5 2 3}$ \\
\hline
\end{tabular}

Sumber: pengolahan data penulis 
Hipotesis pertama menyatakan bahwa saham winners akan terus menjadi winners dan sebaliknya, saham loser akan terus menjadi loser Sehingga dari hasil di tabel 2 tersebut dapat dinyatakan bahwa momentum terjadi pada jangka pendek yaitu untuk holding period 3 bulan. Hal ini dapat ditentukkan dengan membandingkan perbedaan return antara winners dan loserpada periode pengujian atau dihitung dengan zero cost investment strategies (winner-lose). Setelah holding period 3 bulan maka terjadi pembalikan untuk masa holding period berikutnya yaitu untuk holding period 6, 9 dan 12 bulan. Dengan demikian hasil pengujian ini mendukung hipotesis penelitian pertama.
Tabel 2 digambarkan ke dalam Grafik 1 di bawah ini, yang menggambarkan return dari masing-masing pembentukan formation period $(\mathrm{J})$ dan holding period $(\mathrm{K})$. Dari grafik tersebut secara jelas terlihat zero cost portfolio (winner-loser) meningkat pada formation dan holding period mencapai titik maksimum di $\mathrm{J}=12$ dan $\mathrm{K}=3$ dan selanjutnya menurun yang mengindikasikan terjadinya pembalikan (reversal) return untuk jangka menengah. Sehingga dari grafik tersebut, dari penelitian ini profitabilitas momentum terlihat pada jangka pendek untuk semua saham yang terdaftar di Bursa Efek Indonesia.

\section{Zero Cost Portfolio}

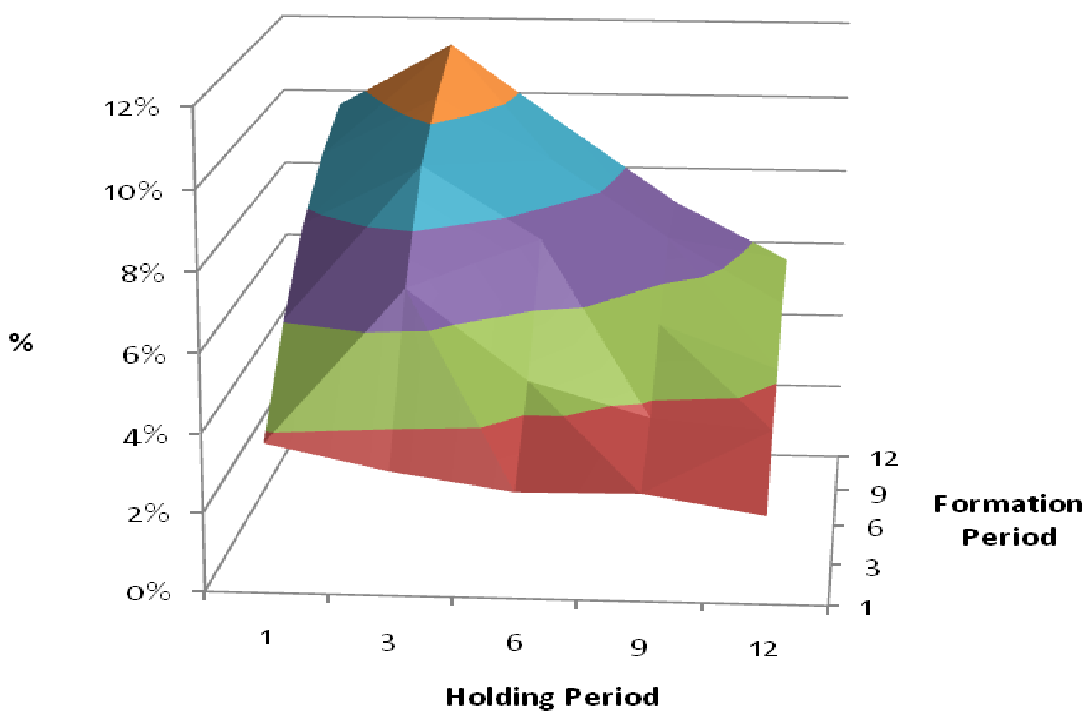

Grafik 1: Zero Cost Portfolio 
Faktor yang Mempengaruhi Profitabilitas Strategi Momentum

Size

Pada penelitian ini untuk menguji pengaruh size terhadap profitabilitas momentum, penelitian ini menerapkan 2 tahap prosedur untuk return dan size. Prosedur pertama, untuk semua saham yang dijadikan sample penelitian, dibentuk 5 quintile portfolio berdasarkan return pada $\mathrm{J}$ bulan dan diurutkan secara descending. Winner portfolio menunjukkan pada quintile yang memiliki return tertinggi dan loser portfolio menunjukkan pada quintile yang memiliki return terendah.
Tabel 3 menunjukkan profitabilitas momentum berdasarkan portfolio size. Winner quintile adalah quintile dengan return saham tertinggi sedangkan loser quintile dengan return saham terendah. Kemudian di-hold untuk $\mathrm{K}$ bulan berikutnya. Kemudian winner dan loser portfolio dibagi ke dalam 5 quintile (S1, S2, S3, S4, dan S5) berdasarkan nilai kapitalisasi pasar pada akhir formation period. Dimana S1 untuk kapitalisasi terbesar hingga S5 untuk kapitalisasi terkecil. Kemudian menghitung return untuk zero cost strategy untuk S1, S2, S3, S4 dan S5. Pengujian ini menggunakan uji t dengan signifikansi sebesar $5 \%$.

Tabel 3: Size Portfolio Return

\begin{tabular}{|c|c|c|c|c|c|c|}
\hline \multirow{2}{*}{$\begin{array}{l}\text { Formation } \\
\text { Period }(\mathbf{J}) \\
\end{array}$} & \multicolumn{6}{|c|}{ Holding Period (K) } \\
\hline & Portofolio & $K=1$ & $\mathrm{~K}=\mathbf{3}$ & $K=6$ & $K=9$ & $K=12$ \\
\hline \multirow[t]{5}{*}{$\mathbf{J}=\mathbf{1}$} & S1 & 0,03192 & 0,03090 & 0,02884 & 0,02989 & 0,02593 \\
\hline & S2 & 0,03565 & 0,03197 & 0,02582 & 0,02813 & 0,02486 \\
\hline & S3 & 0,03934 & 0,03368 & 0,02783 & 0,02728 & 0,02414 \\
\hline & S4 & 0,03979 & 0,03157 & 0,02701 & 0,02454 & 0,02048 \\
\hline & S5 & 0,04281 & 0,02954 & 0,02528 & 0,02636 & 0,01622 \\
\hline \multirow[t]{5}{*}{$\mathbf{J}=\mathbf{3}$} & S1 & 0,05460 & 0,07071 & 0,04745 & 0,03820 & 0,03916 \\
\hline & S2 & 0,06027 & 0,07145 & 0,04714 & 0,03690 & 0,03402 \\
\hline & S3 & 0,06164 & 0,07116 & 0,04625 & 0,03640 & 0,03486 \\
\hline & S4 & 0,06190 & 0,06700 & 0,04418 & 0,03876 & 0,03829 \\
\hline & S5 & 0,06397 & 0,06520 & 0,04532 & 0,03537 & 0,02633 \\
\hline \multirow[t]{5}{*}{$J=6$} & S1 & 0,07252 & 0,09769 & 0,07837 & 0,05776 & 0,05089 \\
\hline & S2 & 0,07735 & 0,09646 & 0,07112 & 0,04909 & 0,03583 \\
\hline & S3 & 0,07835 & 0,09031 & 0,07660 & 0,05395 & 0,04771 \\
\hline & S4 & 0,07780 & 0,09163 & 0,07417 & 0,05417 & 0,04040 \\
\hline & S5 & 0,08186 & 0,08960 & 0,07262 & 0,05020 & 0,03393 \\
\hline \multirow[t]{5}{*}{$\mathbf{J}=\mathbf{9}$} & S1 & 0,08564 & 0,10828 & 0,09564 & 0,07819 & 0,05745 \\
\hline & S2 & 0,08620 & 0,10285 & 0,08366 & 0,06734 & 0,05485 \\
\hline & S3 & 0,09054 & 0,10594 & 0,09041 & 0,07294 & 0,05209 \\
\hline & S4 & 0,08941 & 0,10412 & 0,08797 & 0,06357 & 0,04811 \\
\hline & S5 & 0,09254 & 0,10199 & 0,08432 & 0,05926 & 0,04242 \\
\hline \multirow[t]{5}{*}{$\mathrm{J}=12$} & S1 & 0,09319 & 0,11444 & 0,09705 & 0,08446 & 0,06587 \\
\hline & S2 & 0,09400 & 0,11150 & 0,09101 & 0,07032 & 0,06010 \\
\hline & S3 & 0,09640 & 0,11388 & 0,09551 & 0,07189 & 0,04996 \\
\hline & S4 & 0,09794 & 0,11685 & 0,09241 & 0,07121 & 0,05463 \\
\hline & S5 & 0,09982 & 0,10790 & 0,08231 & 0,05603 & 0,04469 \\
\hline
\end{tabular}

Sumber: pengolahan data penulis 
Langkah selanjutnya, semua saham dimasukkan ke dalam 5 quintile ( $\mathrm{S} 1, \mathrm{~S} 2, \mathrm{~S} 3$, S4, dan S5) berdasarkan nilai kapitalisasi pasarnya pada akhir formation period dimana S1 merujuk pada saham yang memiliki kapitalisasi pasar terbesar dan S5 merujuk pada saham yang memiliki kapitalisasi pasar terkecil. Kemudian di-hold untuk $\mathrm{K}$ bulan berikutnya. Selanjutnya dihitung return untuk zero cost strategy (winner-lose) untuk masing quintile portfolio dari S1, S2, S3, S4 dan S5.

Hasil pada Tabel 3 di atas menunjukan quintile $\mathrm{S} 1$ dengan nilai kapitalisasi pasar terbesar lebih besar dari quintile S5 dengan nilai kapitalisasi pasar terkecil untuk semua formation dan holding period. Profitabilitas momentum terlihat pada pada formation period 3, 6, 9 dan 12 bulan dan pada holding period 3 bulan. Namun setelah holding period 3 bulan terjadi pembalikan untuk holding period selanjutnya. Secara keseluruhan J12/K3 memiliki return yang tinggi di setiap quintilenya dengan rata-rata return sebesar $11,29 \%$.

Sehingga return dari pembentukan size portfolio ini sesuai dengan portfolio profitabilitas momentum yang juga terjadi pada formation dan holding period yang sama. Hasil ini mengindikasikan bahwa portfolio winner untuk perusahaan besar memiliki return yang besar dibandingkan dengan portfolio loserdari perusahaan kecil. Dengan demikian hasil tersebut tidak mendukung hipotesis kedua yang menyatakan bahwa profitabilitas strategi momentum lebih tinggi pada perusahaan kecil.

\section{Trading Volume}

Pada penelitian ini untuk menguji pengaruh trading volume terhadap profitabilitas momentum, sama seperti size, penelitian ini menerapkan 2 tahap prosedur untuk return dan trading volume. Prosedur pertama, untuk semua saham yang dijadikan sample penelitian, dibentuk 5 quintile portfolio berdasarkan return pada $\mathrm{J}$ bulan dan kemudian diurutkan secara descending. Winner portfolio menunjukkan pada quintile yang memiliki return tertinggi dan loser portfolio menunjukkan pada quintile yang memiliki return terendah. Langkah selanjutnya, semua saham dimasukkan ke dalam 5 quintile (V1, V2, V3, V4, dan V5) berdasarkan volume perdagangan pada akhir formation period dimana S1 merujuk pada saham yang memiliki volume perdagangan yang tinggi dan V5 merujuk pada saham yang memiliki volume perdagangan yang rendah. Kemudian di-hold untuk $\mathrm{K}$ bulan berikutnya. Selanjutnya dihitung return untuk zero cost strategy (winner-lose) untuk masing quintile portfolio dari V1, V2, V3, V4 dan V5.

Tabel menunjukkan profitabilitas momentum berdasarkan portfolio volume. Winner quintile adalah quintile dengan return saham tertinggi sedangkan loser quintile dengan return saham terendah. Kemudian di-hold untuk $\mathrm{K}$ bulan berikutnya. Kemudian winner dan loser portfolio dibagi ke dalam 5 quintile (V1, V2, V3, V4, dan V5) berdasarkan volume perdagangan pada akhir formation period. Dimana V1 untuk volume perdagangan tertingg hingga V5 untuk volume perdagangan terendah. Kemudian menghitung return untuk zero cost strategy untuk V1, V2, V3, V4 dan V5. Pengujian ini menggunakan uji $\mathrm{t}$ dengan signifikansi sebesar $5 \%$. 
Jurnal Siasat Bisnis Vol. 12 No. 3, Desember 2008 Hal: 175-186

Tabel 4: Volume Portfolio Return

\begin{tabular}{|c|c|c|c|c|c|c|}
\hline \multirow{2}{*}{$\begin{array}{l}\text { Formation } \\
\text { Period (J) }\end{array}$} & \multirow[b]{2}{*}{ Portofolio } & \multicolumn{5}{|c|}{ Holding Period (K) } \\
\hline & & $\mathrm{K}=\mathbf{1}$ & $\mathbf{K}=\mathbf{3}$ & $K=6$ & $K=9$ & $K=12$ \\
\hline \multirow[t]{5}{*}{$\mathbf{J}=\mathbf{1}$} & V1 & 0,03775 & 0,03510 & 0,03099 & 0,02959 & 0,02765 \\
\hline & V2 & 0,03602 & 0,03288 & 0,02957 & 0,03155 & 0,02608 \\
\hline & V3 & 0,03901 & 0,03404 & 0,02786 & 0,03054 & 0,02341 \\
\hline & V4 & 0,03777 & 0,02934 & 0,02426 & 0,02408 & 0,02059 \\
\hline & V5 & 0,03887 & 0,02628 & 0,02214 & 0,02093 & 0,01387 \\
\hline \multirow[t]{5}{*}{$\mathbf{J}=\mathbf{3}$} & V1 & 0,06174 & 0,07534 & 0,05070 & 0,04041 & 0,03400 \\
\hline & V2 & 0,06053 & 0,07013 & 0,04506 & 0,03797 & 0,03726 \\
\hline & V3 & 0,06584 & 0,07435 & 0,05650 & 0,04789 & 0,04936 \\
\hline & V4 & 0,05634 & 0,06615 & 0,04371 & 0,03818 & 0,03550 \\
\hline & V5 & 0,05804 & 0,05967 & 0,03561 & 0,02277 & 0,01843 \\
\hline \multirow[t]{5}{*}{$J=6$} & V1 & 0,07834 & 0,09854 & 0,07273 & 0,05483 & 0,04271 \\
\hline & V2 & 0,07842 & 0,09628 & 0,07394 & 0,05385 & 0,04602 \\
\hline & V3 & 0,08465 & 0,11027 & 0,08307 & 0,06356 & 0,05497 \\
\hline & V4 & 0,07184 & 0,08937 & 0,08057 & 0,05958 & 0,03715 \\
\hline & V5 & 0,07503 & 0,08221 & 0,06383 & 0,03545 & 0,02940 \\
\hline \multirow[t]{5}{*}{$J=9$} & V1 & 0,08969 & 0,10694 & 0,08861 & 0,07517 & 0,05504 \\
\hline & $\mathbf{V} 2$ & 0,09228 & 0,10861 & 0,09058 & 0,07119 & 0,05644 \\
\hline & V3 & 0,09804 & 0,10975 & 0,09513 & 0,07211 & 0,05720 \\
\hline & V4 & 0,08095 & 0,10222 & 0,08876 & 0,06894 & 0,05213 \\
\hline & V5 & 0,08413 & 0,09626 & 0,08010 & 0,05426 & 0,03530 \\
\hline \multirow[t]{5}{*}{$\mathrm{J}=12$} & V1 & 0,09668 & 0,11444 & 0,09646 & 0,08033 & 0,06587 \\
\hline & $\mathbf{V} 2$ & 0,10011 & 0,11150 & 0,09095 & 0,07229 & 0,06010 \\
\hline & V3 & 0,01051 & 0,11388 & 0,09367 & 0,07370 & 0,04996 \\
\hline & V4 & 0,08763 & 0,11685 & 0,09261 & 0,06798 & 0,05463 \\
\hline & V5 & 0,09264 & 0,10790 & 0,08426 & 0,05982 & 0,04469 \\
\hline
\end{tabular}

Sumber: pengolahan data penulis

Hasil pada Tabel 4 di atas menunjukkan bahwa quintile V1 dengan jumlah volume perdagangan tertinggi akan selalu lebih besar dari quintile V5 dengan jumlah volume perdagangan terendah untuk semua formation dan holding period. Profitabilitas momentum terlihat pada formation period 3, 6, 9 dan 12 bulan dan pada holding period 3 bulan dan selanjutnya terjadi pembalikan (reversal) setelah holding period 3 bulan tersebut. J12/K3 memiliki kinerja portfolio yang lebih tinggi disetiap quintilenya dibandingkan dengan formation dan holding period lainnya dengan rata-rata return sebesar $11,29 \%$.
Sehingga return dari pembentukan portfolio volume ini sesuai dengan portfolio profitabilitas strategi momentum yang juga terjadi pada formation dan holding period yang sama. Hasil ini mengindikasikan bahwa portfolio winner untuk volume perdagangan tertinggi memiliki return yang besar dibandingkan dengan portfolio loser dari volume perdagangan terendah. Dengan demikian hasil tersebut mendukung hipotesis ketiga yang menyatakan bahwa profitabilitas strategi momentum lebih tinggi pada perusahaan kecil. 


\section{PENUTUP \\ Kesimpulan}

Penelitian ini menunjukkan bukti bahwa terdapat profitabilitas momentum pada pasar modal Indonesia selama periode Januari 2003 sampai dengan Desember 2007. Profitabilitas momentum secara signifikan terlihat pada pada periode formasi (formation period) 3, 6, 9 dan 12 bulan dan pada periode penilaian (holding period) untuk 3 bulan. Profitabilitas momentum terbaik terdapat pada J12/K3 yakni dengan profit sebesar $11,28 \%$. Sehingga strategi momentum sangat profitable pada periode jangka pendek yaitu 3 bulan.

Profitabilitas strategi momentum juga dilihat dari variabel size dan volume dimana profitabilitas strategi momentum terlihat pada formation period 3, 6, 9 dan 12 bulan dan pada holding period 3 bulan. Sehingga return dari pembentukan size dan volume portfolio ini sesuai dengan portfolio profitabilitas strategi momentum yang juga terjadi pada formation dan holding period yang sama. Namun, untuk variabel size hasil yang didapat bertentangan dengan hipotesis kedua dimana profitabilitas momentum lebih tinggi pada perusahaan kecil. Sehingga variabel size, untuk penelitian selanjutnya, kurang berpotensi untuk dijadikan variabel yang menjelaskan terjadinya profitabilitas strategi momentum. Penelitian-penelitian berikut dapat mengembangkan pengujian profitabilitas momentum dari variabel lainnya seperti book-to-market ratio (Fama dan French, 1991), firm specific attributes (Sagi dan Seasholes, 2007) yang menggunakan market-to-book ratio, revenue, cost of good sold maupun firm size-book value of total asset. Sehingga nanti dapat dilihat variabelvariabel mana saja yang lebih potensial dan profitable untuk strategi momentum.

\section{Saran}

Hasil dari penelitian ini terlihat adanya profitabilitas momentum pada pasar modal Indonesia, khususnya bursa saham Indonesia, terjadi pada jangka pendek. Dalam implikasi nyata, dimana profitabilitas momentum terjadi pada jangka pendek, investor dapat memanfaatkan jangka waktu dalam 3 bulan dengan membeli sahamsaham yang berkinerja baik dan menjual saham-saham yang berkinerja buruk. Selanjutnya investor juga dapat menggunakan volume perdagangan sebagai referensi untuk menilai saham-saham yang profitable dalam strategi momentum. Strategi momentum juga dapat diterapkan dalam pembentukan portofolio reksadana, dimana para manajer investasi dapat menseleksi saham-saham yang akan mengalami future winner dan future loser dalam pembentukan portofolio reksadana.

\section{DAFTAR PUSTAKA}

Barber and Lyon, J. (1997). Firm Size, Book-to-market and Security Returns: a holdout sample of financial firms. Journal of Finance, $52(2), 875-883$

Chan, Hameed, and Tong. (2000). Profitability of momentum strategies in the international equity market. Journal of financial and quantitative analysis, 35, 153-172

Chui, Titman, and Wei. (2000). Momentum, legal systems and ownership structure: an analysis of asian stock market. Working paper NBER, 1-47

De Bondt and Thaler. (1985). Does the Stock Market Overreact? Journal of Finance, 40 (3), 793 - 805

Drakos and Kallandranis. (2005). FirmsSpecific Attributes of Financing Constraints: The Case of Greek Listed Firms. Investment Management \& Financial Innovations. Vol 2 (2), $98-110$ 
Fama and French, K. (1992). The Crosssection of Expected Stock Returns. Journal of Finance, 47 (2), 427 465

Gertler M. (1988). Financial Structure and Aggregate Economic Activity: An Overview. Journal of Money, Credit and Banking, 20 (part 2), $559-596$

Glaser and Weber. (2002). Momentum and turnover: evidence from the german stock market. Schmanlenbach Business Reviews, 55, 108-135

Hamed and Kusnadi, Y. (2002). Momentum Strategies: evidence from Pasific Basin Stocks Markets. Journal of Financial Research, 25 (3), 383 397

Hong and Stein, J, C. (1999). An Unified Theory of Underreaction, Momentum Trading, and Overreaction in Asset Markets. Journal of Finance, 54 (6), 2143 2184
Jegadeesh and Titman. (1993). Returns to buying winners and selling loosers: implication for stock market efficiency. Journal of Finance, 48 (1), 65-91

Lee, and Swaminathan. (2000). Price momentum and trading volume. Journal of Finance, 55, 2017-2069

Rouwenhorst, K.Geert. (1998). International momentum strategies. Journal of Finance, 53 (1), 267-284

Rouwenhorst, K.Geert. (1999). Local Return Factors and Turnover in Emerging Stocks Markets. Journal of Finance, 54 (4), 1439 - 1464

Sagi and Seasholes. (2007). Firm-Specific Attributes and The Cross-Section Momentum. Journal of Financial Economics, 84, 389 - 434

Womack, Kent L. (1996). Do Brokerage Analysts' Recommendations Have Investment Value? Journal of Finance, 51, 137 - 167 